\title{
Quantifying Effects of Photoperiod, Temperature and Humidity on Flowering Initiation in Basmati Rice Lines
}

\section{Tahir Latif ${ }^{1}$, Zulqarnain Haider ${ }^{1 *}$, Muhammad Ramzan², Muhammad Akhter ${ }^{1}$, Sadia Gull ${ }^{3}$, Abid Mahmood4, Awais Riaz', Rana Ahsen Raza Khan'}

${ }^{1}$ Rice Research Institute, Lahore, Pakistan

${ }^{2}$ Pakistan Agriculture Research Council, Kala Shah Kaku, Pakistan

${ }^{3}$ Yangzhou University, Yangzhou, China

${ }^{4}$ Ayub Agricultural Research Institute, Faisalabad, Pakistan

Email: *z.haider.breeder@gmail.com

How to cite this paper: Latif, T., Haider, Z., Ramzan, M., Akhter, M., Gull, S., Mahmood, A., Riaz, A. and Khan, R.A.R. (2019) Quantifying Effects of Photoperiod, Temperature and Humidity on Flowering Initiation in Basmati Rice Lines. American Journal of Plant Sciences, 10, 893-903. https://doi.org/10.4236/ajps.2019.106064

Received: February 17, 2019

Accepted: June 8, 2019

Published: June 11, 2019

Copyright () 2019 by author(s) and Scientific Research Publishing Inc. This work is licensed under the Creative Commons Attribution International License (CC BY 4.0).

http://creativecommons.org/licenses/by/4.0/

(c) (i) Open Access

\begin{abstract}
The results suggested that all the pure Basmati lines or genotypes initiate flowering within a specific range of day length duration and temperature. Delaying the transplanting date did not significantly affect the flowering time of studied Basmati lines. Maximum threshold of daily minimum temperature (MT) was $24^{\circ} \mathrm{C}$ during both the years. Likewise, maximum threshold of daily day-length (DL) durations was 12 hours and 18 minutes during both the study years. Results showed that the flowering was maximum when the MT and DL values were optimum as depicted by peak of the trend lines, where maximum lines flowered. Maximum flowering initiations took place when DL was about 11 hours and 15 minutes indicating Basmati as short day plant which flowers maximum when day lengths are shorter and dark or night duration is longer. During 2013, 1st date trial showed strong relationship between flowering initiation with dates of flowering during the flowering period as depicted by higher regression $\left(\mathrm{R}^{2}=0.837\right)$ values. In 2 nd date trial during the same year, the value is lower $\left(R^{2}=0.513\right)$ depicting less relationship of flowering initiation with the dates of flowering. The same trend was observed in 2014 trial. In 1st date trial, strong relationship between flowering initiation with dates of flowering during the flowering period as depicted by higher regression $\left(\mathrm{R}^{2}=0.864\right)$ values, was observed. In 2 nd date trial during the same year, the value is lower $\left(\mathrm{R}^{2}=0.1789\right)$ depicting very poor relationship of flowering initiation with the dates of flowering, and the same trend $\left(\mathrm{R}^{2}=\right.$ 0.0544 ) in 3rd date of trial.
\end{abstract}




\section{Keywords}

Basmati Rice, Flowering, Photoperiod, Temperature, Humidity

\section{Introduction}

Basmati is the type of rice (Oryza sativa L.) which is long, slender-grained aromatic rice traditionally from Pakistan and India. Basmati rice is considered sensitive to photoperiod as well as temperature, and is highly affected by these climatic factors resulting in significant yield fluctuations. Time of transplanting is the most important factor among all the agronomic components of yield that directly affect the yield in any crop especially in Basmati rice (Oryza sativa L.) varieties or lines [1]. Three climatic factors i.e. Photoperiod sensitivity, Temperature and Humidity are reported to caste crucial effects in flowering of the Basmati rice lines. Pure Basmati lines only flower between specific ranges of these climatic factors. Any fluctuation in these factors during flowering time results in incomplete flowering. Likewise, during grain filling period, these factors are also of the same importance and significantly affect grain filling and yield reductions. Most of the Basmati rice cultivars are naturally bred to flower between the temperature ranges from 20 to 25 Celsius [2]. Pure Basmati lines twitches anthesis in the last week of September when temperature falls below 25 degree Celsius and completes in flowering within first week October until the temperature falls below 20 degree Celsius.

Transplanting Basmati rice too early or too late, either shortens or prolongs the duration of rice crop respectively from transplanting to panicle initiation causing sterility and lower milling quality. It is observed that variations in growth temperature by varying the transplantation dates caused variation in productivity and quality of rice crop [3]. Previous studies exploring the effects of temperature on kernel development by various researchers have showed that higher temperatures during the plant development stage of grain-filling result in decrease in rice kernel width and thickness and increased chalkiness [4]. However, effects of temperatures on amylase content of different rice cultivars were recorded significantly variable [5]. Too high or too low night time air temperature stress causes reduced substrate supply to the grain endosperm, which results in slow growth of starch granules and irregular granular organization [6]. Ahmed et al. [7] showed that high temperature decreased the grain filling period from 32 to 26 days, reducing yield by $6 \%$.

It has been reported by many researchers that average rice yield as well as its nutritional and cooking quality are significantly affected by weather conditions. Studies carried out on rice demonstrated the negative impact of drastic changes in rainfall patterns coupled with rising temperatures could be managed by changes in planting dates, transplanting dates, transplant age, and crop spacing [8]. 


\section{Material and Methods}

The experiment was conducted during kharif season of 2013 and 2014at the research farms of Rice Research Institute, Kala Shah Kaku in Pakistan. Average, maximum and minimum values of temperature and humidity during months of September and October of both the study years are shown in Figure 1(a) \& Figure 1 (b). Likewise, minimum temperature and day length (photoperiod) values of each day during the months of September and October of both the study years are shown in Figure 1(a) \& Figure 1(b). The experiment was laid out in Randomized Complete Block Design (RCBD) with plot size of $0.229 \times 2.286 \mathrm{~m}^{2}$ replicated twice and thrice in 2013 and 2014 respectively (Table 1). The treatments included two dates of transplanting in 2013 and three dates in 2014. Forty (40) advance rice lines, landraces and cultivars including checks i.e. Basmati 370, Super Basmati were used in the study. Graphs depicted as Figure 2(a) \& Figure 2(b) describes the fluctuations in daily minimum temperature along with the photoperiod/day length durations of the two months during 2013 and 2014 respectively.

Seedlings of 30 days old nursery of each variety were transplanted on a well puddled soil with a spacing of $20 \mathrm{~cm}$ between rows and $20 \mathrm{~cm}$ between hills. Puddling was done by running a cultivator in standing water $(75 \mathrm{~mm})$ followed

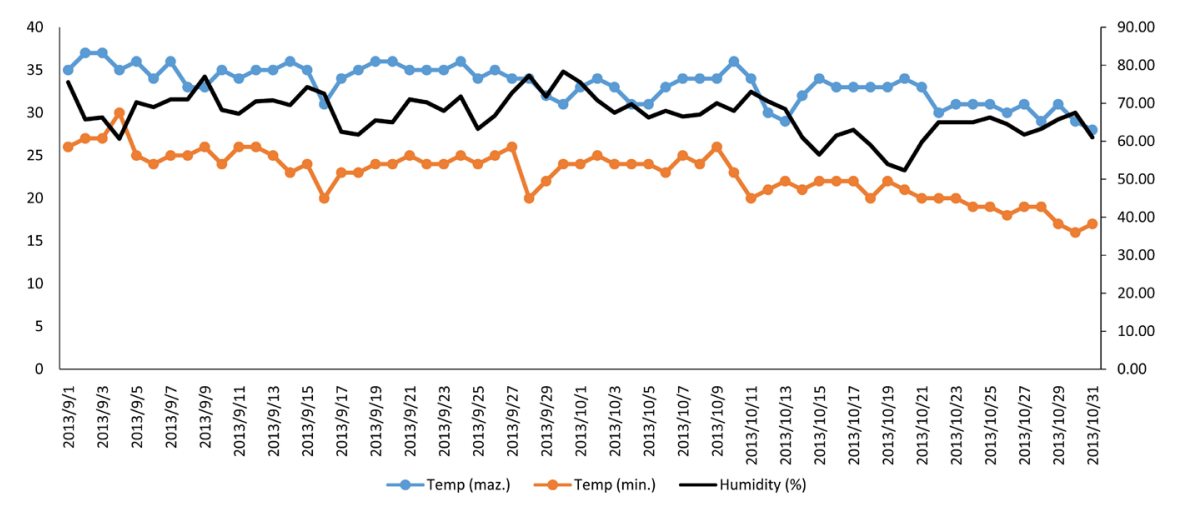

(a)

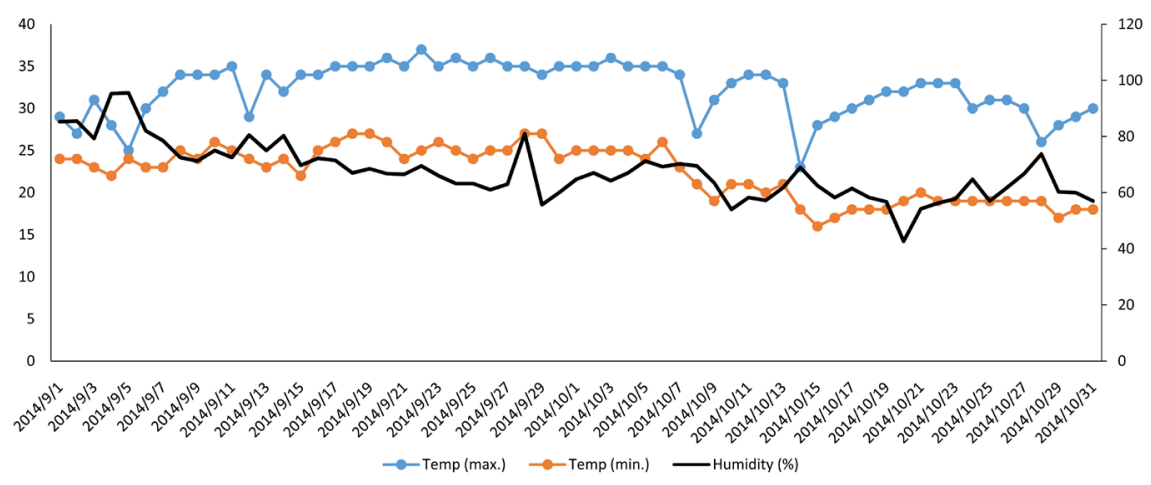

(b)

Figure 1. Daily minimum, maximum and relative humidity of RRI KSK during the months of September and October of both the study years 2013 and 2014. (a) 2013; (b) 2014 . 


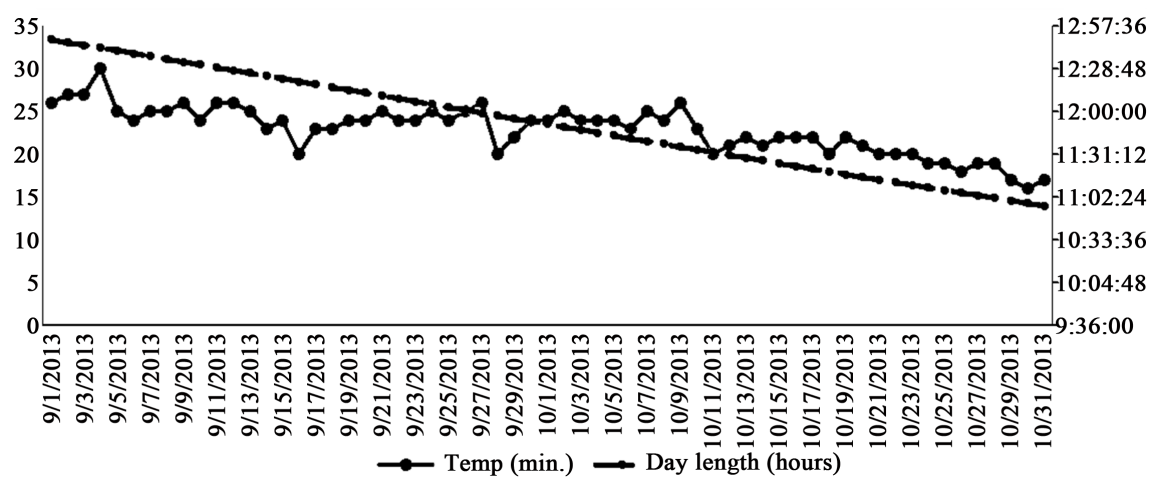

(a)

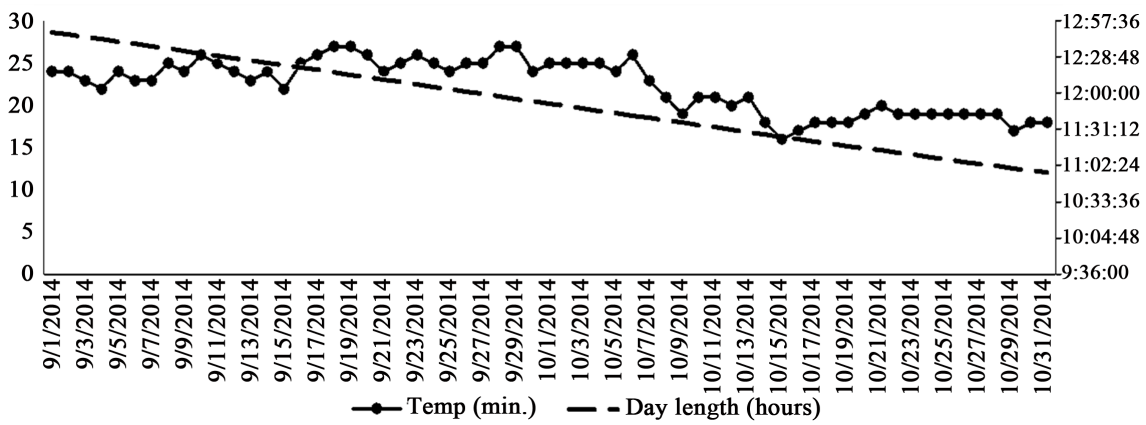

(b)

Figure 2. Daily photoperiod/day lengths and minimum temperatures of RRI KSK during the months of September and October of both the study years 2013 and 2014. (a) 2013; (b) 2014 .

Table 1. Dates of sowing and transplanting during 2013 and 2014.

\begin{tabular}{cccccc}
\hline & \multicolumn{2}{c}{2013} & \multicolumn{3}{c}{2014} \\
\cline { 2 - 5 } & $1^{\text {st }}$ Date & $2^{\text {nd }}$ Date & $1^{\text {st }}$ Date & $2^{\text {nd }}$ Date & $3^{\text {rd }}$ Date \\
\hline Date of nursery sowing & $20^{\text {th }}$ May & $5^{\text {th }}$ June & $28^{\text {th }}$ May & $18^{\text {th }} J$ une & $1^{\text {st }}$ July \\
Dates of nursery transplanting & $25^{\text {th }} J$ une & $10^{\text {th }} J$ uly & $14^{\text {th }}$ June & $19^{\text {th }} J u l y$ & $7^{\text {th }}$ August \\
\hline
\end{tabular}

by planking. Forty $\mathrm{kg} \mathrm{N}$ per hectare was applied at 5 days after transplanting (DAT). The crop was maintained according to the recommended doses of fertilizers. All the other agronomic practices were carried out according to the recommendations. The criterion of the flowering initiation or anthesis was taken as the inflorescences of more than $5 \%$ plants of total population were exerted through the flag leaf (upper most/last leaf) sheath of the main tiller/shoot. Observations were taken each day at about 11.00 a.m.

\section{Results and Discussion}

The results confirmed that almost all the studied Basmati genotypes showed flowering initiation after mid of September both the years and continue flowering till first half week of October. The date of flowering of each lines/genotype is given in Table 2. During the year 2013, $1^{\text {st }}$ date trial, genotypes started flowering on $20^{\text {th }}$ September and continued flowering up to $20^{\text {th }}$ October, while the $2^{\text {nd }}$ date 
T. Latif et al.

Table 2. Dates of flowering initiation of each studied genotype during 2013 and 2014.

\begin{tabular}{|c|c|c|c|c|c|c|}
\hline Sr\# & $\begin{array}{l}\text { Name of } \\
\text { Genotype }\end{array}$ & $\begin{array}{c}1^{\text {st }} \\
\text { Date } 2013\end{array}$ & $\begin{array}{c}2^{\text {nd }} \\
\text { Date } 2013\end{array}$ & $\begin{array}{c}1^{\text {st }} \\
\text { Date } 2014\end{array}$ & $\begin{array}{c}2^{\text {nd }} \\
\text { Date } 2014\end{array}$ & $\begin{array}{c}3^{\text {rd }} \\
\text { Date } 2014\end{array}$ \\
\hline 1 & 454 & 20-Sep & $06-\mathrm{Oct}$ & 22-Sep & 29-Sep & 05-Oct \\
\hline 2 & $1021-3$ & 25-Sep & $06-$ Oct & 27-Sep & 29-Sep & 04 -Oct \\
\hline 3 & $1021-5$ & 24-Sep & $01-$ Oct & 22-Sep & 30-Sep & 02 -Oct \\
\hline 4 & $1021-6$ & 25-Sep & 03-Oct & 27-Sep & 26-Sep & 04-Oct \\
\hline 5 & 33608 & 25-Sep & 07-Oct & 18-Sep & 25-Sep & 27-Sep \\
\hline 6 & 34050 & 30-Sep & $06-$ Oct & 21-Sep & 30-Sep & 02 -Oct \\
\hline 7 & 47456 & $10-\mathrm{Oct}$ & 13-Oct & 17-Sep & 02 -Oct & 12 -Oct \\
\hline 8 & Basmati T3 & 18 -Oct & 18 -Oct & 22-Sep & 27-Sep & 03-Oct \\
\hline 9 & Basmati 385 & 30-Sep & 16 -Oct & 23-Sep & 26-Sep & 04-Oct \\
\hline 10 & Basmati 385-244 & 30-Sep & 16 -Oct & 22-Sep & 22-Sep & 02 -Oct \\
\hline 11 & Basmati 6129 & $20-\mathrm{Oct}$ & 14 -Oct & 21-Sep & 10 -Oct & 12 -Oct \\
\hline 12 & besudi & $07-$-Oct & 14 -Oct & 21-Sep & 22-Sep & 08-Oct \\
\hline 13 & BN 6311 & $06-$ Oct & 14-Oct & 18-Sep & 26-Sep & 08-Oct \\
\hline 14 & Muskhan & 30-Sep & $13-\mathrm{Oct}$ & 17-Sep & 22-Sep & $22-\mathrm{Sep}$ \\
\hline 15 & $\mathrm{~T} 3$ & $07-\mathrm{Oct}$ & 18 -Oct & 24-Sep & 27-Sep & 14 -Oct \\
\hline 16 & $44156 \mathrm{~A}$ & $07-$ Oct & 20-Oct & 19-Sep & 01-Oct & 11-Oct \\
\hline 17 & PK8677 & 25-Sep & $05-\mathrm{Oct}$ & 22-Sep & 29-Sep & 29-Sep \\
\hline 20 & Rexoro & $07-$ Oct & 18 -Oct & 20-Sep & 26-Sep & $30-$ Sep \\
\hline 21 & 98410 & 30-Sep & 19-Oct & 02 -Oct & 02 -Oct & 10 -Oct \\
\hline 22 & 98316 & 30-Sep & $07-\mathrm{Oct}$ & 02 -Oct & 04-Oct & 08 -Oct \\
\hline 23 & PK99417 & 23-Sep & 30-Sep & 22-Sep & 27-Sep & 02-Oct \\
\hline 24 & PK99512 & 30-Sep & $17-\mathrm{Oct}$ & $02-\mathrm{Oct}$ & 06-Oct & 10 -Oct \\
\hline 25 & PK99513 & 30-Sep & $17-$ Oct & 02 -Oct & 02 -Oct & 09-Oct \\
\hline 26 & PK99408 & 30-Sep & $18-\mathrm{Oct}$ & 02 -Oct & 05-Oct & 11-Oct \\
\hline 27 & 99404 & 30-Sep & $05-\mathrm{Oct}$ & $11-\mathrm{Oct}$ & 02 -Oct & 08-Oct \\
\hline 28 & 99515 & 30-Sep & $06-$ Oct & $11-$ Oct & 02 -Oct & 10 -Oct \\
\hline 29 & 1121 & 30-Sep & $10-$ Oct & 26-Sep & 02 -Oct & 08-Oct \\
\hline 30 & PK7392 & 29-Sep & $01-O c t$ & 26-Sep & 27-Sep & 02 -Oct \\
\hline 31 & 515 & 28-Sep & 05 -Oct & 02 -Oct & 02 -Oct & 02 -Oct \\
\hline 32 & 1121 & 30-Sep & $10-\mathrm{Oct}$ & 26-Sep & 02 -Oct & 08-Oct \\
\hline 33 & Basmati 2000 & 27-Sep & $06-\mathrm{Oct}$ & 02 -Oct & 02 -Oct & $08-O c t$ \\
\hline 34 & Pusa Bas 1 & 08 -Oct & $11-$ Oct & $01-$ Oct & 29-Sep & 02-Oct \\
\hline 35 & Pusa Bas 834 & 30-Sep & 18 -Oct & 22-Sep & 02 -Oct & $09-$ Oct \\
\hline 36 & Basmati 198 & $18-\mathrm{Oct}$ & $22-\mathrm{Oct}$ & 17-Sep & 22-Sep & $14-\mathrm{Oct}$ \\
\hline 37 & Basmati 370 & $07-\mathrm{Oct}$ & 12 -Oct & 18-Sep & 23-Sep & $08-\mathrm{Oct}$ \\
\hline 38 & Basmati 370-1 & 18 -Oct & 18 -Oct & 21-Sep & 02 -Oct & 09-Oct \\
\hline 39 & Basmati 370-13 & $07-$ Oct & 18 -Oct & 21-Sep & 02 -Oct & 10 -Oct \\
\hline \multirow[t]{4}{*}{40} & Basmati 370-24 & 29-Sep & 07-Oct & 21-Sep & 30-Sep & $02-\mathrm{Oct}$ \\
\hline & Average & $02-O c t$ & $11-$ Oct & 24-Sep & 29-Sep & 06-Oct \\
\hline & Min & 20-Sep & 30-Sep & 17-Sep & 22-Sep & 22-Sep \\
\hline & $\operatorname{Max}$ & $20-$ - ct & 22-Oct & $11-\mathrm{Oct}$ & $10-$-Oct & 14 -Oct \\
\hline
\end{tabular}


trial, flowering started on $30^{\text {th }}$ September and showed flowering initiation up to $22^{\text {nd }}$ of October in the same year 2013. Similarly, during the second year of study, genotypes transplanted in $1^{\text {st }}$ date, $2^{\text {nd }}$ date and $3^{\text {rd }}$ date started flowering from $17^{\text {th }}$ September, $22^{\text {nd }}$ September and $22^{\text {nd }}$ September respectively and continued flowering initiation up to $11^{\text {th }}, 10^{\text {th }}$ and $14^{\text {th }}$ October of the same year 2014 .

Regression analysis values show trends in flowering initiations in all the studied genotypes with respect to the dates of flowering during the flowering period during both the years 2013 and 2014 as depicted in Figure 3(a) and Figure 3(b) respectively. Higher regression $\left(\mathrm{R}^{2}\right)$ value depicts that the flowering initiations had a strong association with flowering dates while the lower regression values show no or poor relationship of flowering initiation with flowering dates within the flowering periods. During 2013, $1^{\text {st }}$ date trial showed strong relationship between flowering initiation with dates of flowering during the flowering period as depicted by higher regression $\left(\mathrm{R}^{2}=0.837\right)$ values. In $2^{\text {nd }}$ date trial during the same year, the value is lower $\left(\mathrm{R}^{2}=0.513\right)$ depicting less relationship of flowering initiation with the dates of flowering. The same trend was observed in 2014 trial. In $1^{\text {st }}$ date trial, strong relationship between flowering initiation with dates of flowering during the flowering period as depicted by higher regression $\left(\mathrm{R}^{2}=\right.$ $0.864)$ values, was observed. In $2^{\text {nd }}$ date trial during the same year, the value is

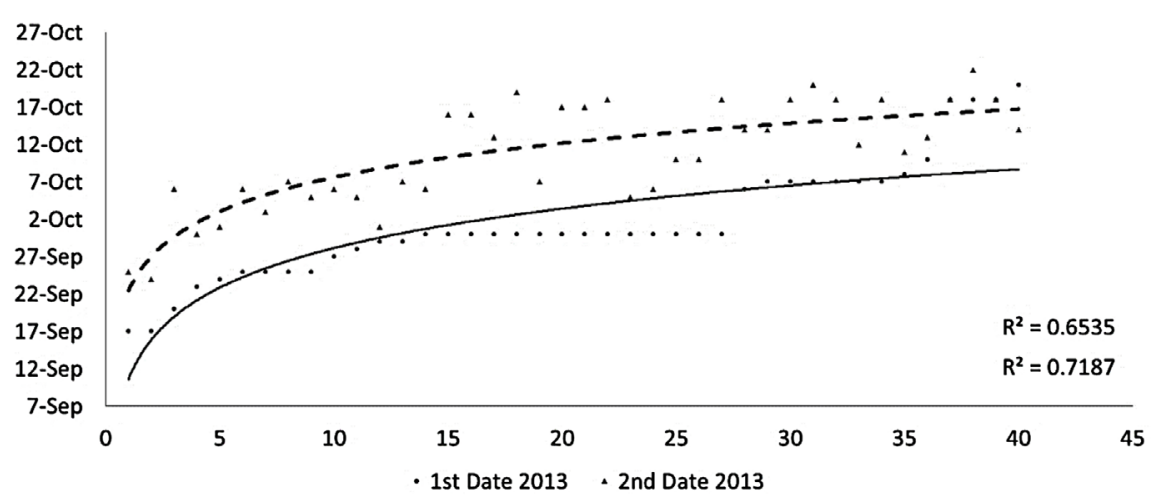

(a)

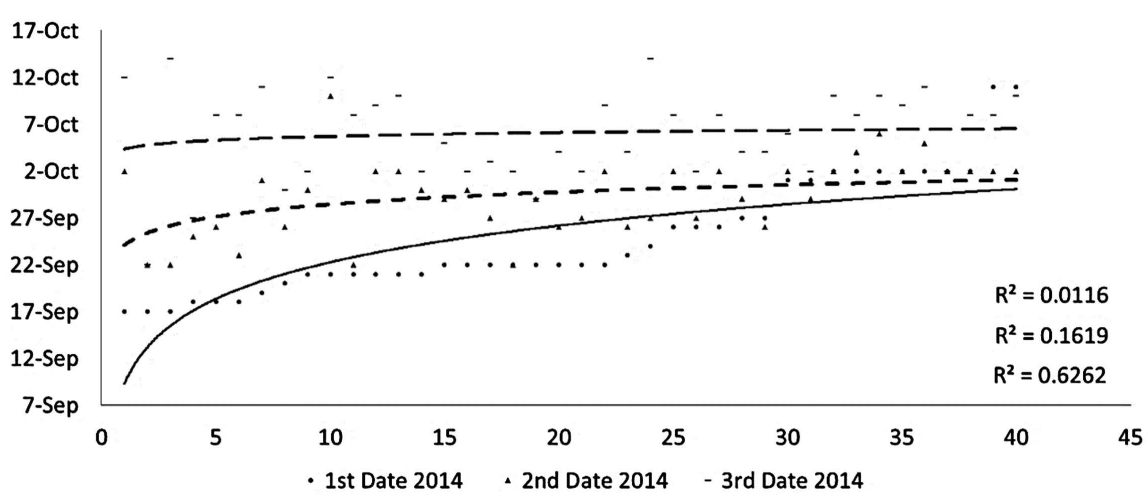

(b)

Figure 3. Regression analysis showering trends of flowering initiation in studied genotypes with respect to the dates of flowering during the flowering period during both the years 2013 and 2014. (a) 2013; (b) 2014. 
lower $\left(\mathrm{R}^{2}=0.1789\right)$ depicting very poor relationship of flowering initiation with the dates of flowering, and the same trend $\left(\mathrm{R}^{2}=0.0544\right)$ in $3^{\text {rd }}$ date of trial. Higher regression values in $1^{\text {st }}$ date trial demonstrates that genotypes initiated flowering over a longer range of days. The difference in flowering initiation in first date trial was due to genotypic differences among the lines for anthesis. While in second date in 2013 and second \& third date trials in 2014, poor relationship showed genotypes flowering over a short range of period of days representing normal period for flowering of Basmati lines.

Trends of flowering initiation in studied genotypes with respect to the dates of flowering, minimum temperature (MT) and relative humidity percentage (RH\%) during the study periods of both the years 2013 and 2014 starting from 1st September to end of October in given in Figure 4(a) and Figure 4(b) respectively. Graphs show that in 2013, flowering started when daily MT fell below $24^{\circ} \mathrm{C}$ down to $20^{\circ} \mathrm{C}$ (on $16^{\text {th }}$ September) and $\mathrm{RH} \%$ below $72 \%$, whereas in 2014 , flowering was initiated as daily MT fell below $24^{\circ} \mathrm{C}$ down to $22^{\circ} \mathrm{C}$ (on $15^{\text {th }}$ September) and $\mathrm{RH} \%$ was again $72 \%$. The data show that maximum limit to start anthesis in Basmati lines is as above as $24^{\circ} \mathrm{C}$ indicating its higher temperature limit i.e. only below this temperature, Basmati lines initiates flowering.

Trends of flowering initiation in studied genotypes with respect to the dates of flowering and daily day length durations or daily photoperiods during the study

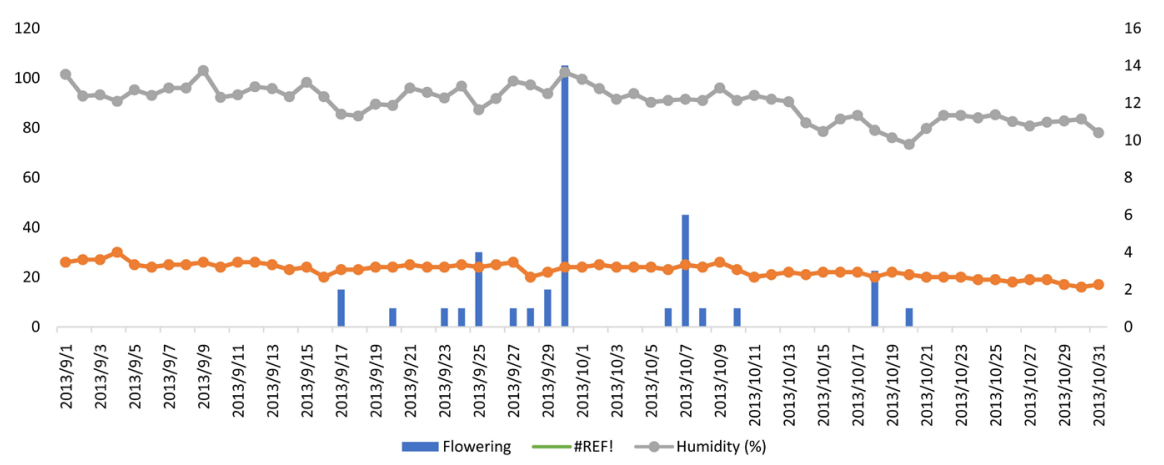

(a)

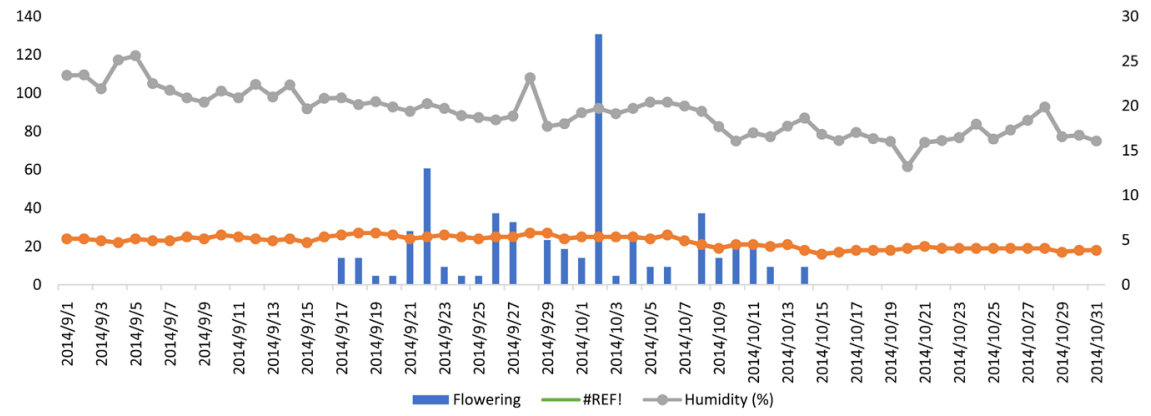

(b)

Figure 4. Trends of flowering initiation in studied genotypes with respect to the dates of flowering, minimum temperature and relative humidity (\%) during the study periods from $1^{\text {st }}$ September to end of October of both the years 2013 and 2014. (a) 2013; (b) 2014 . 
months of both the years 2013 and 2014 starting from 1st September to end of October in given in Figure 5(a) and Figure 5(b) respectively. Graphs show that in 2013, flowering started when daily day-length durations (DLs) or daily photoperiods reached down to 12 hours and 18 minutes, whereas in 2014, flowering was initiated as daily DLs reached down to 12 hours and 18 minutes. The data show that maximum photoperiod/day length duration limit to start anthesis in Basmati lines is as lengthy as 12 hours 18 minutes and continued down to 11 hours 27 minutes and 11 hours 15 minutes during 2013 and 2014 respectively.

Maximum and minimum thresholds of daily minimum temperature and day-length durations for flowering initiation in pure Basmati lines is depicted in Figure 6(a) \& Figure 6(b) respectively. Figure 6(a) clearly shows that all the Basmati lines initiated anthesis after specific range of temperature during both the years. Maximum threshold of daily minimum temperature was $24^{\circ} \mathrm{C}$ during both the years. Likewise, Figure 6(b) clearly shows that all the Basmati lines initiated anthesis after specific range of daily day-length cycles during both the years. Maximum threshold of daily day length durations was 12 hours and 18 minutes during both the study years. Bell-shaped trend lines showed that the flowering was maximum when the $\mathrm{MT}$ and $\mathrm{Dl}$ values were optimum as depicted by peak of the bell-shaped trend lines, where maximum lines flowered. Trend lines in case of MT is slightly projected to right side indicating that maximum

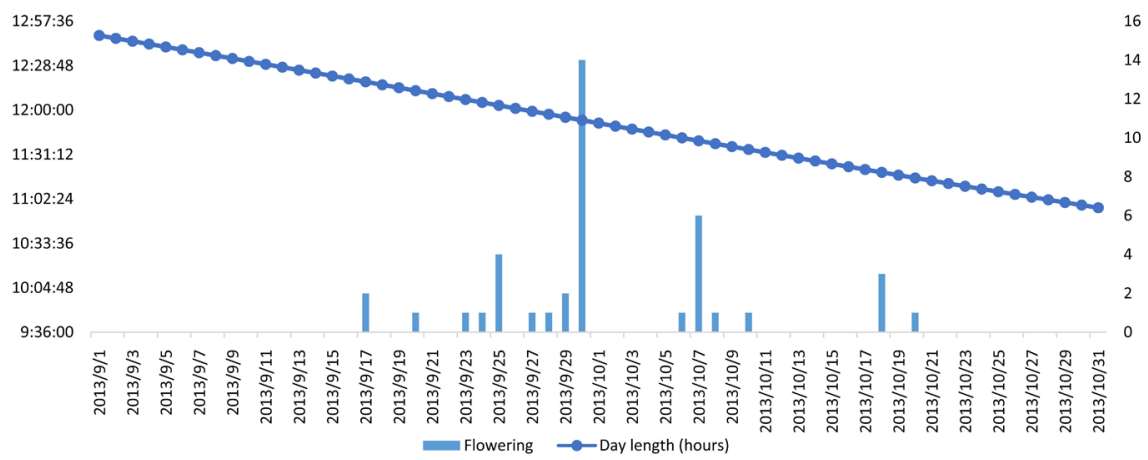

(a)

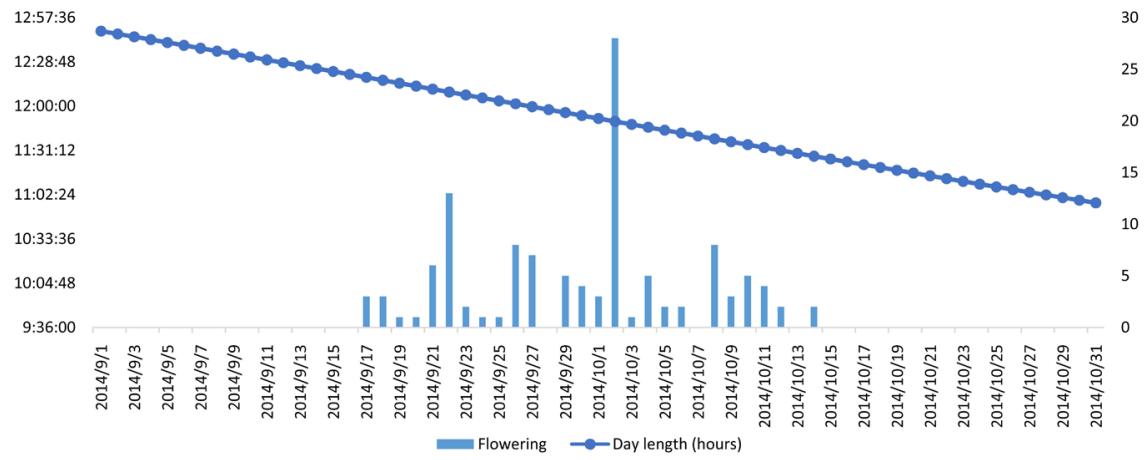

(b)

Figure 5. Trends of flowering initiation in studied genotypes with respect to the dates of flowering and daily day length durations during the study periods from $1^{\text {st }}$ September to end of October of both the years 2013 and 2014. (a) 2013; (b) 2014. 


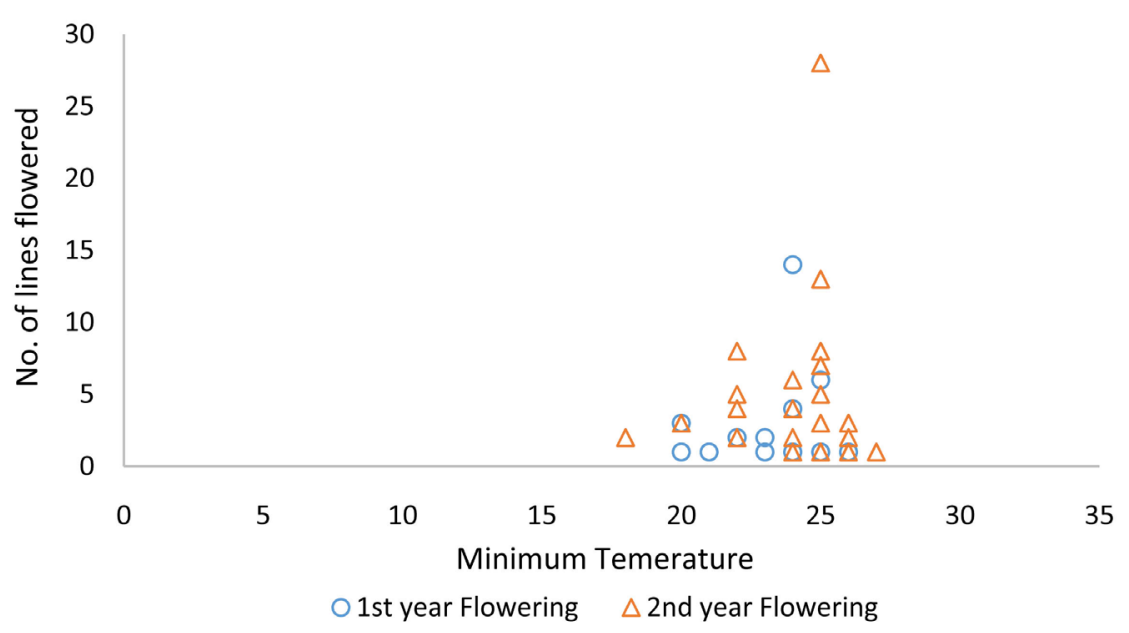

(a)

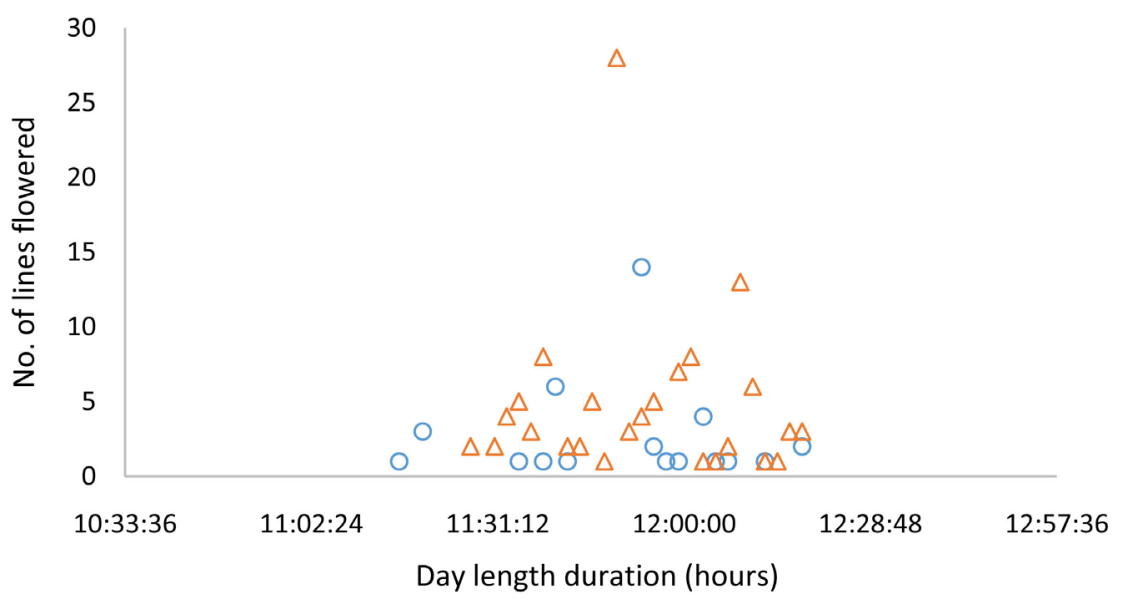

1st year Flowering $\Delta$ 2nd year Flowering

(b)

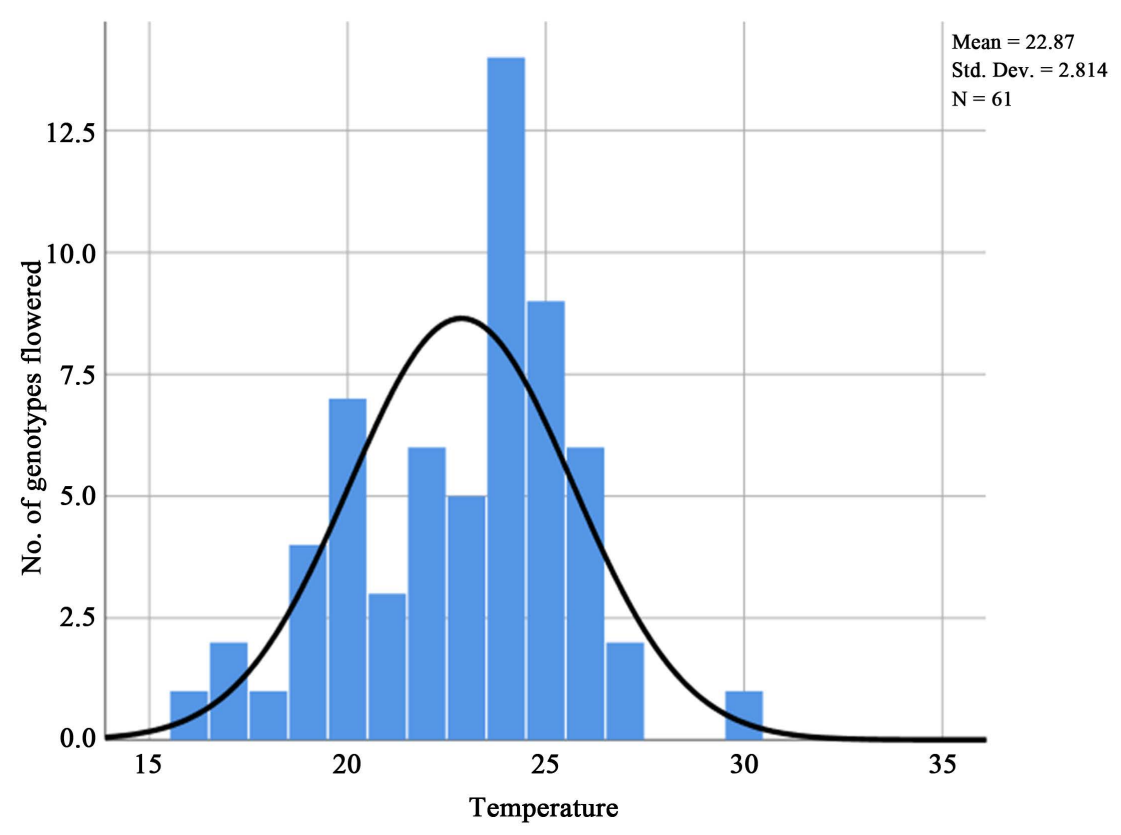

(c) 


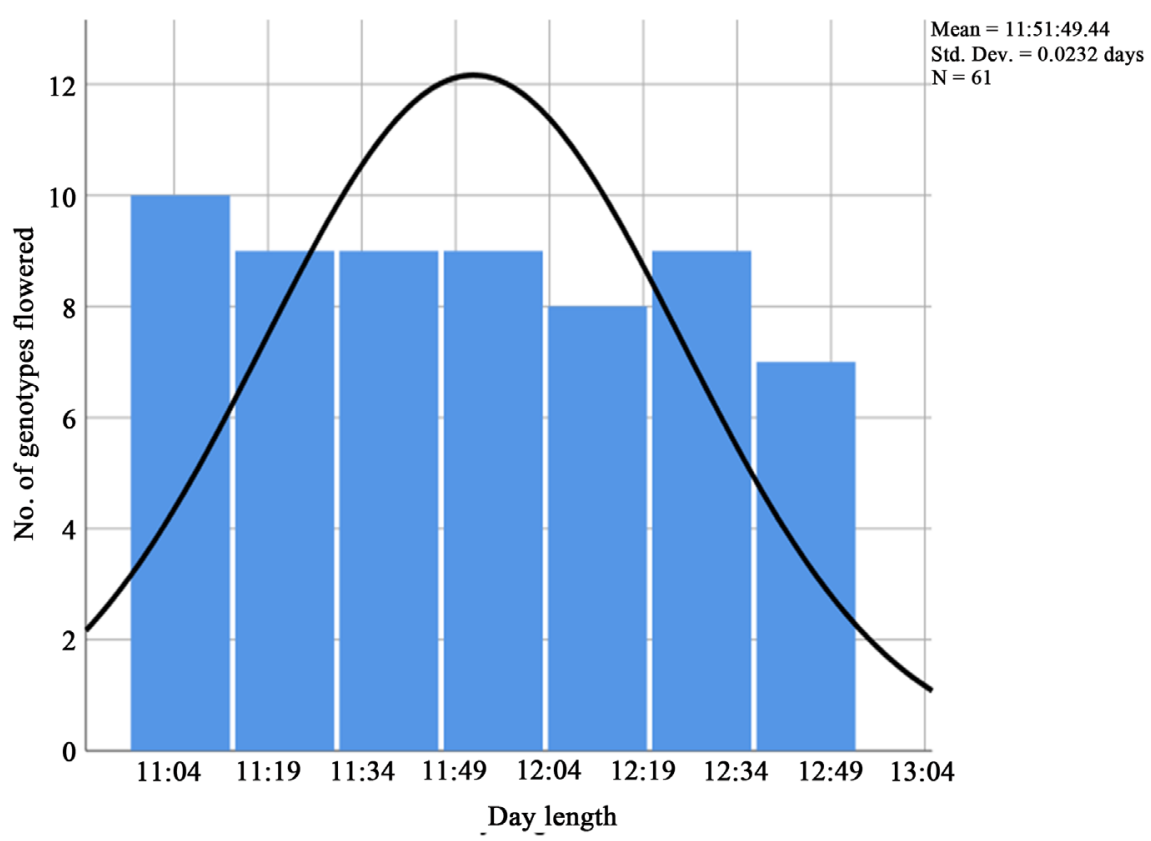

(d)

Figure 6. Scatter plots ((a), (b)) and histograms ((b), (c)) of daily minimum temperature and day-length durations for flowering initiation in pure Basmati lines showing specific range of minimum temperature and day length durations for flowering initiation time in pure Basmati lines.

lines from all the date trials initiated flowering just as the MT fell below $24^{\circ} \mathrm{C}$. however, in case of DLs, maximum flowering occurred at the mid of DL range starting from $12 \mathrm{hrs}$ and $18 \mathrm{~min}$ and continued to $11 \mathrm{hrs} 27 \mathrm{mins}$ while the maximum flowering initiated took place when DL was about 11 hours and 15 minutes indicating Basmati as short day plant which flowers maximum when day lengths are shorter and dark time duration is longer.

\section{Conclusion}

The results suggested that all the pure Basmati lines or genotypes initiates flowering within a specific range of day length duration and temperature. Delaying the transplanting date did not affect the flowering time of studied basmati lines that indicates the lines were pure basmati in nature and had a strong basmati background. Maximum threshold of daily minimum temperature (MT) was $24^{\circ} \mathrm{C}$ during both the years. Likewise, maximum threshold of daily day length (DL) durations was 12 hours and 18 minutes during both the study years. Results showed that the flowering was maximum when the MT and DL values were optimum as depicted by peak of the trend lines, where maximum lines flowered. However maximum flowering initiations took place when DL was about 11 hours and 15 minutes indicating Basmati as short day plant which flowers maximum when day lengths are shorter and dark time duration is longer. During $2013,1^{\text {st }}$ date trial showed strong relationship between flowering initiation with dates of flowering during the flowering period as depicted by higher regres- 
sion $\left(\mathrm{R}^{2}=0.837\right)$ values. In $2^{\text {nd }}$ date trial during the same year, the value is lower $\left(\mathrm{R}^{2}=0.513\right)$ depicting less relationship of flowering initiation with the dates of flowering. The same trend was observed in 2014 trial. In $1^{\text {st }}$ date trial, strong relationship between flowering initiation with dates of flowering during the flowering period as depicted by higher regression $\left(R^{2}=0.864\right)$ values, was observed. In $2^{\text {nd }}$ date trial during the same year, the value is lower $\left(R^{2}=0.1789\right)$ depicting very poor relationship of flowering initiation with the dates of flowering, and the same trend $\left(R^{2}=0.0544\right)$ in $3^{\text {rd }}$ date of trial.

\section{Acknowledgements}

We were cordially thankful to Sadia Gull from Yangzhou University, China for sharing knowledge in writing this manuscript, statistical analyses and its interpretations.

\section{Conflicts of Interest}

The authors declare no conflicts of interest regarding the publication of this paper.

\section{References}

[1] Mahajan, G., Sharma, N., Kaur, R. and Chauhan, B.S. (2015) Comparison of Photoperiod-Sensitive and Photoperiod-Insensitivebasmati Cultivars for Grain Yield, Water Productivity, and Quality Traits under Varied Transplanting Dates in Northwest India. Crop and Pasture Science, 66, 793-801. https://doi.org/10.1071/CP14297

[2] Ferrero, A. and Nguyen, N.V. (2004) Constraints and Opportunities for the Sustainable Development of Rice-Based Production Systems in Europe. FAO Rice Conference, Rome, 12-13 February 2004.

[3] Kaur, A., Kaur, P., Singh, N., Virdi, A.S., Singh, P. and Rana, J.C. (2013) Grains, Starch and Protein Characteristics of Rice Bean (Vignaumbellata) Grown in Indian Himalaya Regions. Food Research International, 54, 102-110. https://doi.org/10.1016/j.foodres.2013.05.019

[4] Tashiro, T. and Wardlaw, I.F. (1991) The Effect of High Temperature on Kernel Dimensions and the Type and Occurrence of Kernel Damage in Rice. Australian Journal of Agricultural Research, 42, 485-496. https://doi.org/10.1071/AR9910485

[5] Singh, N., Paul, P., Virdi, A.S., Kaur, P. and Mahajan, G. (2014) Influence of Early and Delayed Transplantation of Paddy on Physicochemical, Pasting, Cooking, Textural and Protein Characteristics of Milled Rice. Cereal Chemistry, 91, 389-397. https://doi.org/10.1094/CCHEM-09-13-0193-R

[6] Fitzgerald, M.A. and Resurreccion, A.P. (2009) Maintaining the Yield of Edible Rice in a Warming World. Functional Plant Biology, 36, 1037-1045. https://doi.org/10.1071/FP09055

[7] Ahmed, N., et al. (2015) Effect of High Temperature on Grain Filling Period, Yield, Amylose Content and Activity of Starch Biosynthesis Enzymes in Endosperm of Basmati Rice. Journal of the Science of Food and Agriculture, 95, 2237-2243. https://doi.org/10.1002/jsfa.6941

[8] Leng, G. and Huang, M. (2017) Crop Yield Response to Climate Change Varies with Crop Spatial Distribution Pattern. Scientific Reports, 7, 1463.

https://doi.org/10.1038/s41598-017-01599-2 